Rolf Hugoson

Umeå Universitet, Sweden

\title{
CULTURAL LEGACY OR CAPITAL?: TOWARDS A THEORY OF WHAT EUROPEAN CAPITALS OF CULTURE LEAVE BEHIND
}

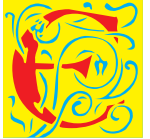

uropean Capitals of Culture $(\mathrm{ECoC})$ is a recent invention, dating back to the middle of the 1980s, when the official title was "European City of Culture". ECoC-events change cities - possibly with the exception of Paris 1989, an event overwhelmingly overshadowed by the revolutionary bicentennial.

In the debate about changes and effects among ECoC:s, the concept of legacy has been introduced. The concept is apparently useful but also problematic and thus interesting to explore, as I demonstrate in the following.

It took a hundred years for the modern Olympians to discover the usefulness of the legacy concept. According to the French historian Chappelet, active in Lausanne: "The concept of legacy is relatively new within Olympic circles: it appeared in the 1990s, during the organizational phase of the 1996 Atlanta games. The private organizers of these centennial games felt compelled to highlight what they would leave behind for the host city." (Chappelet 2008, 1885).

During a formative symposium on Olympic Legacies held in Lausanne in 2002, Australian historian Richard Cashman identified six very broad legacy categories (Cashman 2003: 35ff):
a) economic;
b) built and physical environment;
c) information and education;
d) public life, politics and culture;
e) sport;
f) symbols, memory and history.

A more simple distinction soon ensued between "hard and soft legacies", as Chappelet says: "material legacies such as sports facilities - relatively simple to 
identify - and non-material ones, such as socio-cultural development, which are harder to distinguish" (Chappelet 2008, 1886).

Only when these fin-de-siècle inventions of Olympic legacies appeared well established - through the Sydney Olympics - the concept was imported to the field of European Capitals of Culture. For example, Mary McCarthy, the programme director of Cork 2005, emphasized the value of legacy in 2004, e.g.: "Really, we're in partnership [with the Irish Arts Council] in terms of the legacy onwards." (quoted in Belinda MecKeon, "Cork's year in the limelight", Irish Times Fri, Oct 82004 http://www.irishtimes.com/culture/cork-s-year-in-thecultural-limelight-1.1160996).

More importantly, in the widely read 2004 Palmer report on ECoC:s, a section was entitled: "Legacy and long-term effects" (Palmer 2004: 146). Palmer mention as relevant legacies buildings, projects and organisations. Apparently following the Olympic example, built infrastructure is priority legacy. The term "softer legacies" is used for other legacy forms: "cultural programmes", "the enhancement of experience, skills and confidence" in management and "helping to enhance a city's international image".

A Greek infrastructure project left unfinished during the Thessaloniki ECoC year - thus hardly relevant to the actual event - is somewhat surprisingly identified as good example of legacy by Palmer: "the infrastructure projects were not completed in the cultural year, causing substantial problems and hostile media reaction. But six years later they were complete, offering new facilities for the public and renewed atmosphere to certain parts of the city such as the port. Respondents in most cities were able to point to impressive cultural projects, buildings or organisations that either continued to exist beyond the cultural year or had a long-term impact."

In a 2011 report to European Parliament's Committee on Culture and Education, Beatriz Garcia points at the European Union decision 1622/2006 as the official beginning of ECoC legacy planning. To be precisse, she says that capitals were "planning for the future" already in the 1990s. But only since 2006: "the explicit requirement for the Programme to be sustainable and have a long-term effect has led to more frequent discussion of the need for legacy and some examples of strategic legacy planning." (European Capitals of Culture: Success strategies and long-term effects, EU-Parl 2011: 111 (http://www.europarl.europa.eu/RegData/ etudes/etudes/join/2013/513985/IPOL-CULT_ET(2013)513985_EN.pdf)

Actually, the legacy concept is not mentioned in the October 2006 decision of the EU council and parliament. But article 4 establishes new criteria for 
the cultural programme. This should: "be sustainable and be an integral part of the long-term cultural and social development of the city. [my emphasis]". A programme should also encourage participation and raise the "interest" of citizens and visitors (1622/2006: "Establishing a Community action for the European Capital of Culture event for the years 2007 to 2019").

Garcia herself was highly influential in establishing a link between Olympic Games and cultural events. I have identified three Garcia moments: Firstly, Garcia's $2002 \mathrm{PhD}$ dissertation focused on the Arts Festivals that preceded the Sydney Olympic Games. Whereas the word just had been briefly mentioned by being quoted in her two earlier English language publications, she now used "legacy" no less than nine times (Garcia 2000, 2001, 2002).

Secondly, Garcia in a later article establishes a specific perspective on Olympic cultural legacy: "arts programming has yet to achieve a position that allows it to be perceived as a relevant contributor to the success of major events and their potential regeneration legacy" (Garcia 2004: 104).

Thirdly, in 2006, Garcia became director of the small research team that aimed at following Liverpool's ECoC experience under the name "Impacts 08 ". Legacy aspects were thoroughly emphasized and publicized, adding to the interest created by the recent Palmer report.

Within a few years, the legacy concept was used in other countries, e.g. in Sweden, where Umeås 2008 application for the year 2014 introduces "the legacy" as a headline. But it is worth mentioning that in the Swedish programme version, this headline is simply translated into "After 2014..." (http://umea2014.se/wp-content/uploads/2013/01/ansokan_1_eng.pdf; http:// umea2014.se/wp-content/uploads/2013/01/ansokan_1_sve.pdf).

Indeed, the English word legacy is not easily translated, as already Cashman (2003: 33) noticed at the Lausanne Symposium on Olympic legacies: "there is no precise equivalent to this word in other languages such as French: the word "legs" has a narrow and specific meaning relating to an individual legacy. Hence there was the odd phenomenon that the symposium was advertised as a symposium on legacy (in English) and heritage (in French). If there is such a difference in the meaning of legacy from one European language to another there may be even greater ambiguity when the word is translated into non-European languages."

This translation problem has rarely been identified as a decisive obstacle by the English. In the UK consultancy Ecotec's evaluation of the 2007 and 2008 ECoC:s (Luxemburg GR, Sibiu, Liverpool and Stavanger), several legacy effects 
were identified. Conscious efforts to plan for a legacy was appreciated. For example, Luxemburg's organization: "Ensuring that the positive impacts of an ECOC are sustained may best be achieved through the creation of one or more dedicated legacy bodies; these should be planned from an early stage and, as far as possible, retain key members of staff involved in delivering the ECOC programme" (Ecotec 2009: Ex-post Evaluation of 2007 \& 2008 European Capitals of Culture Final Report, 37). In 2010, Ecotec merged with a Dutch company and was renamed Ecory. But their attention to legacies remained crucial in Ecory's evaluation of the 2010 ECoC:s (Essen/Ruhr, Pecs and Istanbul).

In 2010, the legacy concept was established to a multinational audience at the Brussels conference 'Celebrating 25 years of European Capitals of Culture'. Among the speakers were both Mary McCarthy and Beatriz Garcia. At the conference, the concept was appreciated, perhaps because it captured a vaguely positive impact of ECoC:s (2010: 5): "There is not one unique legacy, nor one single way to be successful; each city must decide on what constitutes success for them and for whom." The short conference summary also included no less than three pages "about legacy" and two pages under the title "How to evaluate legacy?" ("Summary of the European Commission conference 'Celebrating 25 years of European Capitals of Culture” 2010).

Finally, in 2014, the EU parliament and council decided to establish new rules for the ECoC project (EU 445/2014). "Legacy" is now spelled out, in contrast to the 2006 decision. Or rather, this is what occurs in the English text, whereas in other languages we encounter great variety. In English, number 16 of the decision preamble states (emphasises mine in the following quotations): "there should be a particular focus on candidate cities' plans for legacy activities embedded in a long-term cultural policy strategy capable of generating a sustainable cultural, economic and social impact."

This is followed up in Article 5.6: "as regards the 'management' category, the following factors shall be assessed: a) the feasibility of the fund-raising strategy and proposed budget, which includes, where appropriate, plans to seek financial support from Union programmes and funds, and covers the preparation phase, the year of the title, the evaluation and provisions for the legacy activities, and contingency planning".

Also in the following quotations, I have emphasized the "translations" or relevant terms in seven languages I can read, as well as one quotation in Polish a colleague helped me translate. The general tendency is clear: legacy is most often translated as "posterior activities" connected to the ECoC 
event. Only two exceptions occur in my selection. Firstly, there is the Spanish choice of "patrimonio", a word closer to heritage, to be found notably in the Spanish for UNESCO world heritage: "UNESCO patrimonio mundial". Secondly, there is the Polish word "spuścizna", which appears to be quite close to the English "legacy". Because, in Polish, UNESCO world heritage is "UNESCO Światowego Dziedzictwa", thus "Dziedzictwa" corresponds to "heritage".

But, again, the general tendency is translations to "posterior activities":

a) The French text (16): "une attention particulière devrait être portée à la présence, dans les projets présentés par les villes candidates, d'activités ayant des retombées durables" [...5.6] "activités ultérieures".

b) The Italian text (16): "un'attenzione particolare ai piani per le attività legate al titolo"; [...5.6]: "la fase preparatoria, l'anno del titolo, la valutazione e la continuazione delle attività legate al titolo, e il piano di emergenza".

c) The Spanish text (16): "especial hincapié en los planes de las ciudades candidatas relativos al patrimonio integrados en una estrategia de política cultural a largo plazo" [...5.6]: "fase de preparación, el año del título en sí, la evaluación y las provisiones para las actividades relativas al patrimonio, así como los planes de contingencia”.

d) The Dutch text (16): "bijzondere aandacht worden besteed aan de plannen van kandidaat-steden voor activiteiten met langetermijneffecten," [...5.6]: "voorbereidingsfase, het jaar van de titel zelf en de evaluatie, en omvat reserves voor activiteiten met langetermijneffecten, alsmede plannen voor noodsituaties".

e) The German text: (16): "ein besonderer Schwerpunkt auf Maßnahmen mit nachhaltiger Wirkung gelegt werden, die die Bewerberstädte im Rahmen einer kulturpolitischen Langzeitstrategie ” [...5.6]: "Vorbereitungsphase, Jahr der Veranstaltung, Bewertung und Reserven für Maßnahmen mit nachhaltiger Wirkung und Notfallpläne”.

f) The Swedish text (16): "bör särskild tonvikt läggas vid kandidatstädernas planer för uppföljningsverksamhet" [...5.6]:"förberedelsefasen, kulturhuvudstadsåret, utvärderingen och bestämmelser om uppföljningsverksamhet samt beredskapsplaner".

g) The Polish text (16): "należy zwrócić na planowane przez miasta kandydujące działania, które staną się spuścizną obchodów, " [...5.6]: "etap przygotowawczy, rok obchodów, ocenę oraz zapewnienie działań będących spuścizną obchodów, a także plan postępowania awaryjnego". 
However, on the field of European Capitals of Culture, it need not always be the case that official documents in domestic languages have privilege. Except in the French context, English is widely established also as an official language. Much international work is pursued in English, in connection to the cultural capital candidatures as well as in the processes of selection, implementation and evaluation.

Indeed, even in French we encounter efforts to find a reasonable equivalent to "legacy". This happens in documents where past capitals are evaluated. For example, in the evaluation of Košice and Marseille-Provence it is argued that (2013, section 4:8 "Sustainability/ Durabilité / Nachhaltigkeit"): "legacy planning in Košice was well-developed". Whereas the German text here sticks to the vague long-term planning or "Langfristigkeitsplanung", the French on this occasion wrote: "la planification de l'héritage".

Also in Swedish an effort is encountered which appears new when compared to the older documents: "planeringen av arvet" (EU 445/2014). The Swedish word "arv" is close to the German "Erbe" and both belong to the UNESCO world heritage context, German "UNESCO Weltkulturerbe" and in Swedish "UNESCO världskulturarv". But to simply translate legacy with "arv" is not an idiomatic translation.

Although "kulturarv" and "Kulturerbe" means cultural heritage, "arv" and "Erbe" on their own appear as more fundamental notions. When the term "arv" is used in the strict legal sense it presupposes the death of persons: an "arv" is a donation which comes into effect only when the proprietor dies. Although the concept can be used metaphorically in the wider sense, it then usually denotes the passing away of epochs. Therefore, "arv" mix badly with planning for longevity and it is easy to understand why German as well as Danish avoids versions of the Swedish "planerinen av arvet", a clumsy wording which fortunately has remained rare.

However, this odd Swedish translation has been used again in the 2015 evaluation of Riga in Latvia and Umeå in Sweden. Here, the French have "héritage", whereas the Germans again hesitates between "Langzeitwirkungen" and "langfristiger Wirkungen” (EU 2015, 4.7: Sustainability/ Durabilité / Nachhaltigkeit/ Hållbarhetsperspektiv):

i. "The evaluation notes that there were aspects of both cities' approach that showed they had considered sustainability. Although thinking around legacy was established early on in the ECOC lifecycle of each city, this did not however manifest in a strong longer term legacy or sustainability plan to sustain the cultural offer beyond the title year itself." 
ii. "Enligt utvärderingen visar vissa aspekter i de båda städernas program att de arbetade ur ett hållbarhetsperspektiv under planeringen. Trots att frågan om arvet från kulturhuvudstadsåret togs upp tidigt i planeringsarbetet i de båda städerna, gjordes ingen plan för att fortsätta arvet och utvecklingen i syfte att upprätthålla det kulturella utbudet även efter själva året.”

iii. "L'évaluation note que certains aspects des approches des deux villes montrent qu' elles ont tenu compte du critère de durabilité. Bien que la réflexion sur l'héritage ait été établie à un stade précoce du cycle de vie de chacune des CEC, cela ne s'est toutefois pas traduit par un plan solide en ce qui concerne l'héritage ou la durabilité à long terme, qui permettrait de maintenir l'offre culturelle au-delà de l'année de la manifestation elle-même."

iv. "Im Evaluierungsbericht wird angeführt, dass es in der Vorgehensweise beider Städte Aspekte gab, die zeigten, dass Nachhaltigkeit ein Thema war. Zwar wurde schon früh im Kulturhauptstadtzyklus beider Städte über Langzeitwirkungen nachgedacht, dennoch wurde kein besonderer Plan zur Sicherung langfristiger oder nachhaltiger Wirkungen erarbeitet, um das Kulturangebot über das Kulturhauptstadtjahr hinaus aufrechtzuerhalten.”

Interpreting this field of linguistic differences, it seems that the English original "legacy" occupies a terminological space between "heritage" and "bequest", without cutting of the relations with these alternative words, yet conveying a rather vague image of something being benevolently passed on in time.

A legacy can also be a gift; indeed, according to the English dictionary definition this is something given away in a will or handed down by a predecessor and the origin is the Latin "legatus": "Late Middle English (also denoting the function or office of a deputy, especially a papal legate): from Old French legacie, from medieval Latin legatia 'legateship', from legatus'person delegated' (see legate)." (http://www.oxforddictionaries.com/definition/english/legacy).

Tentatively, we might say that English historical usage has taken the opportunity to mix up of the two Latin words "legatus" (a legate or envoyé) and "legatum" (a testamentary bequest). When this Latin couple legatus and legatum has been imported to other languages, the meanings have usually been kept separate. This might explain why many Western European languages lack an obvious translation of the very English "legacy". As noted, the polish "spuścizną" might tempt us into assuming that Slavonic languages have less difficulties in finding a good translation. 
But in many languages, there are only three rather awkward alternatives:

a) either a choice of a vague term, such as in EU 445/2014 varieties of "long-term planning" in Dutch, French, German, Italian and Swedish;

b) or the "heritage" option, such as the Spanish "patrimonio" and sometimes (e.g. in the evaluation reports quoted above) the French "héritage";

c) or, finally, the choice of a legal term closer to the English "bequest", Latin "legatum" or the French "legs"; this last solution can be found in some Italian translations, where we encounter "lascito" (EU 2015): "Sebbene la riflessione sul lascito dell'azione sia stata prevista in uno stadio precoce del ciclo di vita di ciascuna delle capitali europee della cultura, questo non si è tuttavia tradotto in un solido piano sul lascito o sulla sostenibilità a lungo termine per mantenere l'offerta culturale oltre l'anno in questione".

Now, we could of course rejoice and say that this is excellent news. Europe is a plurality in cultural terms, why we should avoid placing words in straight-jackets, defining them with too much rigor.

Let the Germans say langfristiger, the French heritage, the Spanish patrimonio and the Italians lascito. Yet, we must note that this is not the official strategy. The diversity of translations are not emphasized in any official document I have encountered. Translations are without exception presented as faithful copies.

Perhaps scholars can contribute here, by distinguishing differences as well as similarities and making comparisons relevant also to practitioners. In other words, let's not stick to the legacy wording but look and see if other words better would help us exploring the topic, what European Capitals of Culture leave behind.

Precisely when we discuss what to do with what is left over, we might need to begin by talking also about the concrete aspects of the particular mixtures of capacities, resources, capital, stock, leftovers and spoils to be found in cities, whether they made it to the Europan Capitals of Culture or not. erhaps we ought to talk about more about Urban Capital than about Urban Legacies?

\section{References}

Carhman, R., "What Is 'Olympic Legacy'?, in: The Legacy of the Olympic Games, 19842002, eds. M. de Moragas, Ch. Kennett and N. Puig. Documents of the Olympic Museum. Lausanne: International Olympic Committee, 2003, 31-42.

Chappelet, J.-L., "Olympic Environmental Concerns as a Legacy of the Winter Games", The International Journal of the History of Sport, 2008, 25:14. 
Chloé, M., L’UNESCO de 1945 `a 1974. Histoire, Paris I: Université Panthéon-Sorbonne, 2006. https://tel.archives-ouvertes.fr/tel-00848712/document

Garcia, B., "Comparative analysis of the Olympic Cultural program, design and management of Barcelona '92 and Sydney '2000," in: K. B., Wamsley, S. G., Martyn, G. H., MacDonald \& R. K. Barney (eds.), 5th International Symposium for Olympic Research, London: International Centre for Olympic Studies - University of Western Ontario, 2000, 153-158.

Garcia, B., "Enhancing Sport Marketing through Cultural and Arts Programs: Lessons from the Sydney 2000 Olympic Arts Festivals," Sport Management Review, 2001, 4, 193-219.

Garcia, B., Towards a Cultural Policy for Great Events. Local and Global Issues in the Definition of the Olympic Games Cultural Programme. Lessons from the Sydney Olympic Arts Festivals 1997-2000, PhD Universitat Autonoma de Barcelona, 2002. http://hdl.handle.net/10803/4111

García, B., "Urban Regeneration, Arts Programming and Major Events," International Journal of Cultural Policy, 2004, 10(1), 103-118.

Palmer 2004, European Cities and Capitals of Culture. Study Prepared for the European Commission, Part I, Palmer/Rae Associates, Brussels, 2004.

Report from the Commission to the European Parliament, the Council, the European Economic and Social Committee and the Committee of the Regions, Ex Post evaluation of the 2013 European Capitals of Culture (Košice and Marseille-Provence). http://eur-lex.europa.eu/legal-content/EN/TXT/?uri=CELEX\%3A52015DC0074

Report from the Commission to the European Parliament, the Council, the European Economic and Social Committee and the Committee of the Regions, Ex Post evaluation of the 2014 European Capitals of Culture (Umeå and Rìga). COM/2015/0580 final. http://eur-lex.europa.eu/legal-content/EN/TXT/?uri=CELEX\%3A52015DC0580

"Celebrating 25 years of European Capitals of Culture" (2010). ec.europa.eu/programmes/... europe/.../conclusions_ecoc_en.pdf

European Capitals of Culture: the road to success - Europa.eu. ec.europa.eu/programmes/... europe/actions/.../ecoc_25years_en...

European capitals of culture success strategies and long-term effects. www.europarl.europa. eu/RegData/etudes/.../IPOL-CULT_ET(2013)513985_EN.pdf

European Capitals of Culture - Europa.eu. ec.europa.eu/...europe/...europe/.../capitals-culture-city-own-gui...

European Capitals of Culture Legacies « ICC Liverpool. iccliverpool.ac.uk/?research=european-capitals-of-culture...

European Capital of Culture | Dr Beatriz García. www.beatrizgarcia.net/?cat=105

http://ec.europa.eu/programmes/creative-europe/sites/creative-europe/files/files/capitals-culture-2010-report_en.pdf

http://data.europa.eu/eli/dec/2014/445(1)/oj DECISION No 445/2014/EU OF THE EUROPEAN PARLIAMENT AND OF THE COUNCIL of 16 April 2014 establishing a Union action for the European Capitals of Culture for the years 2020 to 2033 and repealing Decision No 1622/2006/EC 